
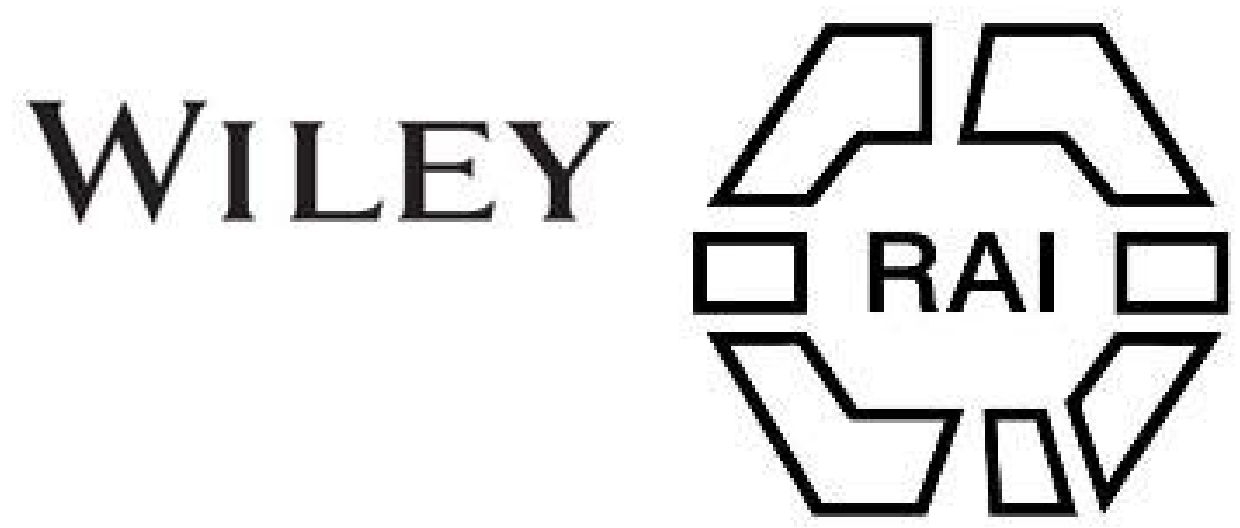

\title{
106. New Ireland (New Mecklenburg) Myths
}

Author(s): W. H. Cox

Source: Man, Vol. 13 (1913), pp. 195-199

Published by: Royal Anthropological Institute of Great Britain and Ireland

Stable URL: http://www.jstor.org/stable/2787594

Accessed: 27-06-2016 02:31 UTC

Your use of the JSTOR archive indicates your acceptance of the Terms \& Conditions of Use, available at

http://about.jstor.org/terms

JSTOR is a not-for-profit service that helps scholars, researchers, and students discover, use, and build upon a wide range of content in a trusted digital archive. We use information technology and tools to increase productivity and facilitate new forms of scholarship. For more information about JSTOR, please contact support@jstor.org.

Wiley, Royal Anthropological Institute of Great Britain and Ireland are collaborating with JSTOR to digitize, preserve and extend access to Man 
(Breasted); and a slit-like aperture (H) was often made to open into the chapel, as a means whereby the spirit could pass into the chapel and enjoy the food provided for it.

This conception of the serdab as a dwelling-place for the dead man's spirit appealed strongly to the imagination of a superstitious people; and when the mastaba came to be imitated by less skilful workmen amidst less cultured peoples, say, for example, in the case of an Egyptian dying in some foreign country, where there were no craftsmen capable of carving statues, the serdab would still be retained. In fact it came to be looked upon as the most essential part of the superstructure, for was it not the dwelling for the dead man's spirit, and as such the means whereby that spirit could be prevented from wandering abroad and annoying the living. Thus the $\operatorname{serd} b^{*}$ increased in size and importance.

In the Sardinian "Giant's Tomb" (Fig. 2) the Egyptian mastaba-construction is most closely followed, for all of the following features (in addition to the characteristic orientation) are preserved :-The chapel of offerings (C), usually called the forecourt, with a large carved stela $(\mathrm{H})$, which is also the "holed stone"; the greatly overgrown serdab (S), the western end of which has become merged in the burial chamber (B), the tumulus (T), and its retaining wall (M). The size of the tumulus, and consequently the form of its retaining wall, is very variable, and in the solitary instance of this type of grave found in Ireland these features were missing.

When thus stripped of its investments (tumulus and retaining wall) the chapel and the overgrown serdab (which is now also the burial chamber) alone remain (Fig. 3), and the result is the allee couverte. The rough representation of the human figure sometimes found in the vestibule (chapel) of the allée couverte (Fig. 3, a), alongside the holed stone (stela) corresponds to the bas-relief of the deceased found alongside the false door in the chapel of the Egyptian mastaba (Fig. 1, a), and the "cup markings" of the dolmen probably symbolise food offerings.

The smaller "holed dolmens" (Fig. 4), whether they occur in Europe, the Caucasus, or India, represent a further simplification of the allee couverte, and among people who could not bore a hole in a stone slab, the eastern wall was omitted (Fig. 5). Thus the crudest form of rough dolmen is the descendant of the serdab of the Egyptian mastaba.

G. ELLIO'T SMITH.

\section{New Ireland: Mythology.}

New Ireland (New Mecklenburg) Myths. By Rev. W. H. Cox, Ulu, Bismarck Archipel.

Origins.

There are variations in the stories told of the beginnings of man as we know him.

One story is that the maker, or father, of all things is Larunaen, whose seat is in the west-a matana labur, the face or the source of the north-west winds. His feet reach to the matana taubara, the face or the source of the south-west winds.

His wife, Hintabaran, a woman of an evil spirit, was really his sister, and was called a nuna harahut (his helper), and all people are his descendants.

When they multiplied Larunaen made the earth so that he could send away those whom he did not wish to stay longer with him, and so we have the present population.

Those who remained with Larunaen are called a mataneabar na tadar (the people of the gods).

* Dr. Alan Gardiner tells me that in the anicent texts refereaee is made to the dead man himself, and not his spirit, as the worker of evil. 
Another story is that before Larunaen were Soi and Tamono, who in every version occupy an important place. They were married to two women who came from a large forest tree which burst and gave them forth. These two couples are the ancestors of man.

According to both versions Larunaen provides man with all that he needs to sustain bodily life. All food comes from Larunaen, and whenever there is a shortage, such as is caused by drought, Larunaen is blamed. It is said that someone has annoyed him and in his anger he withholds the needed rains.

Earthquakes are supposed to be caused by Larunaen. When they are felt Larunaen is said to be on the move.

Man came from the west, and Soi and Tamono are respectively the heads of the two great classes-Maramara aud Pikalaba, into which all the people are divided.

The sending of the population abroad and the division into classes is said by some to have taken place at a spot to the north-west where a crooked cocoanut called Satale stands. By others it is said that the population coming from the seat of Larunaen moved south and east, and about Eratubu they were divided into two classes-Maramara and Pikalaba.

The relations between Soi and Tamono are regarded as constantly antagonistic, an attitude which gives rise to a multitude of myths and legends.

Soi is the head of the Maramara class. He is the representative of wisdom and in all his habits and customs is an intelligent being. Hence the bird chosen as the totem of the class is the taraqau (fish-hawk), a bird clever and capable in its own calling. Soi ate only good food-taro, etc.-and all he did was done properly.

Not so Tamono who is the head of the Pikalaba class. He was an incapable foolish fellow. He ate poor and mean food, bitter and undesirable things. He could not do anything right. This is suggested in the choice of the Miniqulai or Malaba (an eagle) as the totem of the class. The Taraqau is the fisher and the Miniqulai gets his food by stealing from the Taraqau. He will chase the Taraqau, and when the latter drops his fish the Miniqulai swoops down and catches it ere it reaches the water or the ground. Hence the Miniqualai is classed as a Kaloata, the name by which those who do not go to sea are known.

Members of the Maramara class are said to be known by the fact that when they step out to walk they lift the right foot first, while the Pikalaba lift the left foot first.

As in other parts, marriage between members of the same class is forbidden. The children follow their mother and belong to her class. The children of a man cannot marry the children of his sister, though of course they belong respectively to different classes-the relationship is the barrier.

Some of the stories told of Soi and Tamono:-

Soi was the man of intelligence; he was also unscrupulous and bad. By sorcery and other means he is said to have duped and wronged and destroyed the relatives of Tamono, and by degrees to have become possessed of their property, so that he was a rich and important chief.

Tamono, on the other hand, was a fool, and frequently fell an easy victim to the deceptions of Soi. Soi had but to tell him that something he was doing was wrong, and, right or wrong, he would turn round and do it the reverse way, frequently bringing on himself ridicule.

Some of Tamono's relatives were in a large house, and Soi visiting them saw their valuables, shell-money, etc., and made up his mind to have them. "Let us sleep," he said. As they slept Soi went round and tied them all together by heads and feet alternately, that is, he tied together the heads of two, then he tied the foot 
of one of those to the foot of his next neighbour, and his head to the head of the next, and so on. He then went out and shut the door and set fire to the house. The inmates awoke startled, and wished, of course, to run out, but found they were tied together and perished.

The women and goods were in another house, and Soi got all, and so from being a poor man became a rich one and a chief.

\section{Sol's Ruse to get a Meal of Fish.}

A number of Tamono's relatives came in with a lot of fish, and Soi, having none, wished for them. So he said to the people, "Come to my breadfruit tree and get " some breadiruit to eat with the fish." They went, but Soi ran on ahead and climbed the tree and waited for them. As they commenced to climb the tree to pick the fruit Soi called to them one by one, "Kinaua na ulilig, kinaua na kulap," which is a playful way of speaking of one climbing and springing and leaping like an opossum. When they got up the tree he would take a very ripe fruit and throw it at their heads. They would get a great shock as the squashy thing broke over their heads. They thought their brains had come out and in the shock fell down dead. So he did with them one by one, and having disposed of them went back to the village and enjoyed a good meal of fish.

\section{After Death.}

New Ireland (N.M.) natives believe that after death they go to what is known as a matan. A hole in a cliff or the opening of a small cave is called a matan. Such a hole is to be seen at Nokon, on the east coast, its distinctive name being Matantabaran (the entrance to the abode of spirits).

A man of angry and unkindly spirit is frequently remonstrated with by his acquaintances, who warn him that he will not go to a matan. Imaginary stories are told of those who, travelling along the bush paths after the death of such a man, find here and there the roots of trees which cross the path with bark freshly scarred, which they believe to have been done in the flight as the deceased was chased from the matan by its occupants.

Communication with the departed is supposed to have taken place on some occasions, as witness the following story :-

A man's wife, who was a specially fine woman, died, and her husband was in great sorrow for her. He missed her very much and wished for her and wept sorely. One night, as be slept in his house, he dreamt that his wife was at the place which is known by the natives as the resort of the spirits of those who have passed away. He got up and went off to the place, and, standing on a small rise close to, he looked towards the sea and watched for what might be seen. Soon a number of spirits came down to bathe, and he strained his eyes to see if his departed wife would show herself. By-and-bye he saw her and greatly desired to get in touch with her. As he looked he remembered a bunch of betel-nut and a small packet of wild pepper which were at his house, and he thought, If I should bring them and throw them to her she would recognise them and think of me, and perhaps I would be able to speak to her. He acted on the thought and ran home and got the betel-nut and pepper and brought them and threw them at his wife from where he stood. She picked them up and she said to herself, These are like the betel-nut, etc., which were hanging at our door, and having noticed the direction from which they came she went up to where her husband was. He said to her, "I have been in great sorrow for you." "Do not come near me," she said. He said, "I want you to come back " with me; there is no woman like you-I want you badly." "I cannot come," she said. "Come," he said, "do come with me." "I cannot," she said, "your body " and mine are different. I cannot come back with you." At the same time the 
male spirits, who were bathing, came towards her and called her, "Come here." "Go," she said, "go home, or else they will see you and some harm will come to you. By" and-bye you can come and waken me," meaning that by-and-bye he would die and join her in the home of spirits.

He went off greatly disappointed and was in great sorrow on the way home. He told what he had seen-that his wife had appeared to him-and died.

\section{The Heaventy Bodies.}

The sun and moon are looked on as the rulers of the heavens. The sun is called Maluaga and the moon Hintogolopi. When there is a death the relatives wait till the sun is covered with a cloud, when they beat their drums and blow their shells and cry out, "Ui, Maluaga, una marasai ra num taman na kareka" ("You sun " (Maluaga) pity your village of fowls," a humble designation for lowly-minded folk).

They reverence and pray to the moon in the same way.

They have names for a number of the stars, such for instance as the morning star. It is interesting to note that they call the evening star a tagul a hasaro (the deceiving star), because it appears in the evening, but soon sets, so that its promise is not fulfilled.

The changing positions of some other stars are also noticed and their relation to the seasons noted.

\section{A Source of Mysteries and Valuables.}

Sikodo is a fabulous giant who is the source of the ugut. (The ugut is a method of fishing with traps made of the thorny ends of a species of "wait-a-bit" vine. The thorny pieces are put together in the shape of a cone, and when the fish puts its nose inside to get the bait the reversed thorns prevent it from getting out again.) He, Sikodo, made some traps and went to the beach to go fishing with them. He covered his canoe with leaves to protect it from the sun, and put his traps and some small fish for bait near at hand, and in the evening went out to fish. In the meantime a boy-Padamalana-hid himself in the canoe and when Sikodo got to sea suddenly the boy started up. Sikodo got a great surprise and was very angry with the boy, and said to him, "Who are you? Where have you come from?" "I am your nephew," he said. So Sikodo permitted him to stay, and showed him how to use the traps. They caught many fish. Sikodo strung the fish on a piece of cane and reached out his long arm from the sea and put the fish at the door of the house of Padamalana's mother. This was to signify that Padamalana was catching fish.

They returned and Padamalana accompanied Sikodo to his home in the bush, called Matanalulur, i.e., a deep hole in the rocks. Sikodo taught Padamalana all his sorcery, and the words of the petitions which are religiously sung in connection with the using of the traps.

(Sikodo had as his servants the taraqau or fish-hawk, and the malaba or eagle respectively, the totems of the Maramara and Pikalaba classes, and they and Padamalana all lived together.)

When Padamalana had learned things he was to return home, but Sikodo said first to him, "Be blind." He lost his sight and Sikodo took him in his hand and put him at his home.

Note.-Sikodo was a great giant and had a very long arm, and being on Laur was able to deposit things at a great distance-even at Duke of York Group.

When Padamalana opened his eyes he saw a great heap of fish which had been put in front of the house by Sikodo on their behalf. The people asked Padamalana who canght the fish, and he said that he himself had. He went again to Sikodo and the latter taught him how to make the traps-every detail. 
Sikodo stretched out his long arm and dipped the point of his finger in the sea, and the fish for a great distance in all directions were killed. There was a great stench and many people died of the smell. This was spoken of as the destruction by poisoning or shooting of Sikodo-a hunhun te Sikodo.

\section{A Legend.}

One day Sikodo told Padamalana to make a hat boroi-a representation of a smooth stone said to resemble a pig. He made it of sand on the beach-dark sand on one side and light on the other. Padamalana brought the people to see it. They had to pay to do so with magin (shell money) and dogs' teeth. In return for this payment they were taught the songs of the kalaua (ugut fish traps) and initiated into the catching of fish in this way. The hat boroi was decorated with all kinds of fish and seaweeds, \&c. When all was finished Padamalana spread the sand out again, breaking down the whole thing.

On one occasion Sikodo taught Padamalana how to catch fish with a net. They went out to sea and had a tremendous haul-sharks, turtles, porpoises, and all kinds of great fish.

All kinds of valuables-shell money, sharks' teeth, \&c., had their source in Pada-magin, who got them from Sikodo.

On one occasion Pada-magin went to Sikodo's place and saw a fine basket of magin (shell money)-10 "men" which means 200 fathoms-20 fathoms being counted a "man"-one for each toe and finger of the body.

As his uncle, Sikodo, gave it to Padamalana he went and distributed it to the people, and so the use and circulation of magin commenced.

W. H. COX.

\section{Africa, East.}

\section{A Few Notes on the Wasanye. By A. Werner.}

While at Witu on December 9, 1912, I had, through the kindness of the

Werner. Sultan, an opportunity of seeing three Wasanye of that district and obtaining a few specimens of their language. Unfortunately, my stay was too short to allow of more than one interview, and this is the more to be regretted as the Wasanye in the district (Mambrui) only speak Galla and appear to have no knowledge of any other language. The numerals given me by the Witu Wasanye were as follows:-

$$
\begin{array}{lrlrl}
1 & =\text { Watukwe. } & 6 & =\text { Tawate Olu Watukwe. } \\
2 & =\text { Lima. } & 7 & =", \text { Olu Lima. } \\
3 & =\text { Kăva }(\underline{\mathrm{V}}=\text { bilabial v). } & 8 & =" \text { Olu Kăva. } \\
4 & =\text { Sa'ala. } & 9 & =" \text { Olu Sa'ala. } \\
5 & =\text { Tawate. } & 10 & =\text { [Kumi. }]
\end{array}
$$

I do not know whether the word for "ten" was given me by mistake, or whether they have adopted the Bantu one.

The other words obtained were :-

Bow = ala.

Bowstring $=$ doo.

Quiver = kirangati.

Salutations :-

On meeting : Faide-Andŭla-Niso-Roiga.

On parting : Amani kuu (Swahili?)-Kai kawatichi

I obtained a phonograph record of the numerals and two songs, but I fear not a very successful one.

The first song, described in Swahili as a "song of magic" (Wimbo wa uganga), [ 199 ] 